\title{
13. Art Works From Home, Out of Place
}

\author{
Helen Idle
}

'... art is never an end in itself, it is only a tool for blazing life lines ...'

(Deleuze and Guattari 2004, p. 208)

At the entrance to the exhibiton of Australian Indigenous art in the German city of Cologne in 2011, 'Remembering Forward: Australian Aboriginal Painting since 1960', I can just see over the shoulder of the gallery guard collecting tickets and into the first room. On a near wall I see something familiar. I recognise colours, texture and shape, and am brought to tears. I've sat on the ground in Gija country with my hand resting on the ochres of pink, white and yellow, similar to those used in the painting I see now. In Purnululu, under a deep overhanging rockface carved out of towering striated rocks, I sat with my sandwich and listened to the Indigenous guide sing the hymn 'How Great Thou Art' so it echoed through the cave-like surround. My uncle was being cremated at just that moment 1,000 miles to the south in Perth. I recall grief and the ache of mourning on first sight with this painting in Germany and am pulled into a dialogue with it.

The painting is a white ochre square disrupted by a black-filled curve entering the painting from one corner, bounded by white dots, and a smaller white-filled curve framed in black with a white dot border entering part way across one edge. Opposite are two circles. One, painted white, is entirely enclosed by the central area and the other is floating into the far edge with a black frame holding it. The inner white area is smeared with pink ochre, coming from a darker intense spot and pulled out in many directions, over and over again blending outwards in multiple layers. Short brushstrokes appear to flicker outward from this darker pink centre creating a sense of movement, gradually occluding the under white and black ground. Short, sharp, small movements imitating the flicker of fire. The painting is Old Bedford (2005) by Gija artist Paddy Bedford of the Kimberley region of north Western Australia.

In this intense moment of being, while genuinely experiencing the abiding now, nunc stans, I am alive to the present, the future, and the past. The call for an ego-histoire in 2013/14, if I've understood correctly, counters this experience by asking the writer to attend to her past. In the act of identifying aspects of my ego-histoire for this paper, I am challenged to narrow my perspective. My English version of ego-histoire dulls the senses with its demand to work 
within conventions of history making. How can I account for my transnational, global and even planetary histories? Should I declare a magpie-like intellectual journey from secondary school existentialism to undergraduate phenomenology and post-structuralism to post-colonialism and interdisciplinarity some 20 years later as a master's student? As the sole student in a secondary school French class, I read Camus and Sartre and tangled with existentialism-teenage angst writ large. This influenced my understanding of the world, and created an ontological reality that separated me from my family and friends. Passerini and Geppert note that most of the participants in the ego-histoire edition of Historein 'consider themselves as outsiders. Even Pierre Nora', and they ask whether we should consider 'Self- fashioned marginality, then, as a leitmotiv of the entire genre?' (Passerini \& Geppert 2012, p. 14).

I am the outsider, white Australian in Cologne, looking at Indigenous painting in a modernist white cube art museum. Considering Mieke Bal's idea that a viewer can engage more deeply with a work of art by entering into a dialogue with it, by hearing what it 'says' or what theory it can make-listening to the art rather than talking over the experience - I am minded to work where 'thought processes emerge in the dynamic between the works as objects, their viewers, and the time in which these come together' (Bal 2010).

This viewing moment initiates a dialogue about beauty, pain, disruption, and terror. It creates a space of loss, grief, mourning, and shame. The painting tells me a story that is confusing, painful and appropriately full of loss. The work refers to the fire lit during the Bedford Downs Massacre in the 1920s. A group of Aboriginal men were accused by settlers of killing a bullock, they were chained and forced to fell trees that were then used to make a pyre upon which they were thrown after being fed poisoned food (Clement, 2003, p. 8). Paddy Bedford and other Gija artists paint this event and other massacres in the Kimberley region of Western Australia. The exhibition 'Blood on the Spinifex' displayed the work together in Melbourne and the catalogue interview with Paddy Bedford, in reference to another of his paintings, Two Women Looking at Bedford Downs Massacre, reports the massacre: 'Well this is the place where my old boss killed lots of people at one time, the killing place near the emu dreaming at Mount King.' (Starr 2002, p. 25).

My immanent moment with Bedford's work is further complicated by a blush of - is it shame, insecurity, a sense of not knowing where I should be? Elspeth Probyn has proposed using shame to 'generate new ways of thinking about how we are related to history and how we wish to live in the present' (Probyn 2005, p. 162). In that instance of the blush I am caught looking at the massacre and am confused by where to place myself in relation to it: I am made 'alive' to 'my relations to others' (Probyn 2005, pp. 34-35). These are not relations that can 
be resolved or solved, but enlivened by the act of looking. I'm being asked to consider my relation to Gija people and to that event in 1920s, as well as to my uncle's death.

My area of research is the experience of viewing contemporary visual art by Indigenous Australian artists in exhibition in western Europe. I'm working towards new methodologies and frameworks for critical analysis of this workin particular 'out of country' - that may contribute to ways of exhibiting Australian Indigenous art in Europe. I am a PhD candidate at King's College London. This paper endeavours to show how I come to this area of study and demonstrates one way in which the immanent moment of contact between the viewer (me) and artwork - both of us away from 'home' and 'out of place' may generate a deeper understanding of my relationship to country as a nonIndigenous Australian, and freshly negotiate my relationship with Australia from afar.

The obvious question is: why do I focus my research on Indigenous Australian art rather than non-Indigenous or plain Australian art displayed over here? The display of Indigenous art troubled, and still troubles, curators: the authenticity of the works is under scrutiny and too often no one knows where it should be displayed - in an ethnographic museum or a white cube? Where does it belong?

... within whiteness's regime of power, all representations are not of equal value: some are deemed truthful while others are classified as fictitious, some are contested while others form part of our commonsense taken-forgranted knowledge of the world. (Moreton-Robinson 2004, p. 76)

The British artist Grayson Perry, broadcasting to the UK through the Reith Lectures on BBC Radio 4, commented on particular Indigenous work shown in the Royal Academy exhibition 'Australia' (a display including Emily Kngwarreye, John Mawurndjul and Rover Thomas):

... they're powerful ethnic items, but are they contemporary art? You know, they look like abstract specialist paintings, but are they, you know, because do they know about the contemporary art world? I don't know (Perry 2013).

On hearing the ignorance expressed so clearly and shamelessly, on hearing longestablished artists being insulted and their existence in effect denied, I am tipped into anger. I feel defensive of Indigenous artists, of Australia, and of myself. There are so many problems with Perry's observations yet they are helpful as a high-octane example of the racism which fixes Indigenous Australians into the ancient past. This questioning of your ontological reality, the essence of self, is a sure route to conflict. Being questioned as to whether you are real or not, to account for your very existence, is a daily challenge when living away 
from home, and in the capital city of colonialisation, London. The marginal and unsettling nature of the work in display and associated discourse, resonate lightly with my own out of placeness. I acknowledge that this in itself could be a problematic white strategy of using the other to interrogate self, something I write to elsewhere.

So where do I belong?

I come to my area of interest because I am a white Australian of settler-colonial heritage, born and raised in Noongar country, Western Australia, living in London. I live with an attachment to, and disconnection from Australia created by the 'tyranny of distance' (Blainey 1967), one that forges a space for me to examine my relationship to Australia through these works of art, where the artworks look back at me in my 'out of placeness'. Although choosing to live in the UK, I yearn for Western Australian country, for what is now, some 30 years after my first leave-taking as a young adult, an imagined place. This never to be fulfilled desire to be at home in country, in Balardung country east of Perth, where as a young white girl I had the freedom to roam and explore, protected partly by being recognised as the headmaster's daughter and partly by not yet being old enough to be prey for bored teenagers. It's a pretty ordinary story of a sandy-haired kid from country Western Australia, of Protestant colonialsettler heritage. 'Your girls read too much!' I recall my maternal grandmother whispering to her teacher-daughter, my mother. She was right. I read too much and learnt of places beyond the boundaries of my physical, emotional and psychological limits. Beyond the limits of niceness and pressed tea towels and freshly laundered dresses for 'best'. I grew to question the rules of 'best' behaviour and what made 'good girls' by speeding in cars on dirt roads with boys after school, or playing loud rock music on a bright orange record player (now in the care of a musician nephew), and reading about anarchy and feminism in the back of the secondary school's driving lesson car whilst my friends sat in the front learning to drive. All these ideas from countries far away-I barely heard anything of Indigenous stories, only those interpreted and sanctified by book publishers.

Our family moved every two years. My girlhood was largely formed in country Western Australia. Although we were free to roam in Balardung country, east of Perth, as far as a bicycle and the heat would allow, in Kaniyang country (south-west) we were bounded by a sense of foreboding and threat from the bush at the end of the orchard, 'so thick a dog can't bark in it'. Our parents, both West Australian born - a city slicker and a country girl - shared what they knew and loved of the bush by teaching us the English names of the plants and showing us secret places to find wildflowers: donkey orchids, spider orchids, prickly bacon and egg plants. Although at the age of seven my mother could catch, skin and cook a rabbit far from the farmhouse where she lived, 
she never taught me or my sisters. At the age of seven I was eating at a diner in New York City, in casual conversation with a publicity manager for the Beatles and Rolling Stones (accompanied by parents, I hasten to add). We'd been living in Seattle for 12 months.

My teacher-parents presented books for birthdays and Christmas. I read Enid Blyton, Ruth Park, Alistair McLean, Arthur W. Upfield, Henry Lawson, Banjo Patterson, Robert Frost, and John O'Hara. At school my father introduced me to Henrik Ibsen, Gerard Manley Hopkins and T. S. Eliot while he was my final year literature teacher, reading aloud long passages, performing his love of the ballad form. Combined, these experiences allowed me to imagine somewhere else, somewhere beyond country Western Australia. Yet day-to-day I attached myself to my immediate natural world by learning to note its changes and variety as taught by my country-grown mother, thus making a felt connection to wherever we were living at the time. It is country that I hear and smell. My heritage is not of that country, I don't hold the custodianship of it in any formal way as my fellow Indigenous schoolchildren may. But I have a yearning for it, especially from far away.

As an adult now living in London for more that 20 years, my imagined home is still of country Western Australia, Balardung country, places that are flat, golden-brown with a rustling lizard, and have vast blue skies with a soaring bird. My inner landscape is filled with these smells, sounds, and memory of a physical body heated by sun and brushed with dust. In some essential way, this is where I believe I belong. I look for connection to home in my London life through looking and experiencing artworks from 'home', here out of country. My research project considers the display and exhibition of Australian Indigenous artworks in Europe and, in seeking critical approaches shaped by the fact that they are being displayed 'outside' country, I am called to think about myself out of place as well. In fact, my non-Englishness, or non-Britishness, is underlined and my accent provokes endless enquiries as to where I am from. With the benefit of living in a huge cosmopolitan centre I am not seeking to fix my identity to any one type, despite some British people's subtly expressed anxieties at my being just that little bit different.

My grandmother played the church organ. My grandmother played golf. My grandmother made cheesy twists in a wood stoked oven surrounded by apple trees. My grandmother was connected to the country, to Noongar country, from a wadjela settler family, we are told.

As children grown in the country we heard tales of forebears, settling as freemen in south Western Australia: hardworking people who faced physical 
and emotional challenges that long sea voyages between England and India, or between Ireland and Van Diemen's Land may have prepared them for. We heard of the successes and of some losses. We learned of mental health crises, of the world wars separating families. Of a great uncle buried at the roadside where he fell while fighting in France.

Our women carried the stories and fluffed them into good shape while we grew untended in the bush behind the house. We didn't hear of the massacres, the conflicts and confusion here/there on Noongar soil. The hospitality of our Indigenous hosts was unrecognised.

In the moment of looking at artworks brought from Australia for display in Europe I want the representations of longed-for home to afford me a heartfelt experience. On occasion the works touch me and make a connection for me to the land, even if not my specific country-Noongar country-but country I have been in and lain upon. And I can sense the space, and air and light that feed the gap between here and there. I want this art to work as a bridge to somewhere else, and to the other, and to me, holding me in relation to Australia and to being alive.

Mine is an ordinary, mongrel-style, colonial-settler story.

I could be the great-great-granddaughter of an Irish-Australian's love affair with a Spaniard, resulting in a love child born in 1869, or was it 1897, named Augustus Ricardo. I could be the descendent of a gold miner, robbed of his nugget in the goldfields of Western Australia in 1890s by his American partner, who he then chased on foot some 600 kilometres to the port, only to see the ship leaving.

I could be the great-great-granddaughter of a woman from Nhill near Glenrowan who rode with Ned Kelly. I could be the great-granddaughter of a shopkeeper and drunk.

I am the granddaughter of an electrician and a clerk. I am the daughter of teachers.

I am connected to a beach between Cottesloe and Fremantle, Leighton, named for my paternal great-great-grandmother who managed the railway gates there where the new surf club crouches.

I am connected to the land by barefoot stubbed toes and sun-scarred eyes. I am connected to place by a longing to lie down in the hot red dirt and dive into the deep blue sky. 
My body cells were struck under the Southern Cross in a springtime romance by people connected to the bursting of rough wildflowers and the swell of the Indian Ocean.

In a white cube in a city shaken by war I am overwhelmed with a sense of loss as my eyes light across chalky white and soft pink surfaces of a painting from home. A tingle of anticipation; am I going to be comforted? No. Everything is not going to be alright now.

\section{Acknowledgements}

I'd like to thank the referees and Anna Cole for their guidance, and the editors for their commitment to this project. With thanks also to Ian, Jan, Lesley and Joan for their feedback during the writing of this paper. All errors are mine alone.

\section{References}

Bal, M 2010, 'After-Images: Mere Folle', Nomadikon, Available at: http://www. nomadikon.net/ContentItem.aspx?ci=172 (accessed 22 October, 2010).

Blainey, G 1967, The Tyranny of Distance: How distance shaped Australia's history, Sun Books, Melbourne.

Clement, C 2003, 'National Museum of Australia Review of Exhibitions and Public Programme Submission', National Museum of Australia. Available at: http://www.nma.gov.au/about_us/nma_corporate_documents/exhibitions_ and_public_programs_review/submissions/.

Deleuze, G \& F Guattari 2004, A Thousand Plateaus: Capitalism and schizophrenia, translated by B Massumi, Continuum, London.

Kalgoorlie Western Argus 1905, 'Extensive Horse Sale', Kalgoorlie Western Argus, 1 August, 1905, p. 15. Available at: http://nla.gov.au/nla.newsarticle33026480 (accessed 23 December, 2013).

Konig, K, E Joyce Evans \& F Wolf (eds), 2010, Remembering Forward: Australian Aboriginal Painting Since 1960, Museum Ludwig and Paul Holberton Publishing, Cologne and London.

Moreton-Robinson, A 2004, 'Whiteness, epistemology and Indigenous representation', in Moreton-Robinson, A (ed.), Whitening Race: Essays in social and cultural criticism, Aboriginal Studies Press, Canberra, pp. 75-88. 
Ngapartji Ngapartji, In Turn, In Turn: Ego-histoire, Europe and Indigenous Australia

Passerini, L \& A Geppert 2001, 'Historians in Flux: The concept, task and challenge of ego-histoire', Historein, vol. 3. Available at: http://www. historeinonline.org/index.php/historein/article/view/96/94.

Perry, G 2013, 'Playing to the Gallery', Reith Lecture, BBC Radio 4, 22 October, 2013.

Probyn, E 2005, Blush: Faces of Shame, University of Minnesota Press, Minneapolis.

Starr, B (ed), 2002, Blood on the Spinifex, The Ian Potter Museum of Art and the University of Melbourne, Melbourne. 
This text taken from Ngapartji Ngpartji: In turn in turn:

Ego-histoire, Europe and Indigenous Australia

Edited by Vanessa Castejon, Anna Cole, Oliver Haag and Karen Hughes,

published 2014 by ANU Press, The Australian National University, Canberra, Australia. 